\title{
Copper-zinc superoxide dismutase in Haemophilus species
}

\author{
Paul R. Langford, ${ }^{*}$ Barbara M. Loynds and J. Simon Kroll \\ Molecular Infectious Diseases Group, Institute of Molecular Medicine and Department of Paediatrics, Oxford University, \\ John Radcliffe Hospital, Oxford, OX3 9DU, UK
}

(Received 26 September 1991; revised 21 November 1991; accepted 12 December 1991)

\begin{abstract}
Copper-zinc superoxide dismutases ([Cu,Zn]-SODs) are ubiquitous in eukaryotes but have rarely been found in prokaryotes. A gene for $[\mathrm{Cu}, \mathrm{Zn}]-\mathrm{SOD}$ (sodC) has recently been cloned from Haemophilus influenzae type b and $H$. parainfluenzae, so other Haemophilus and related species were screened for the presence of [Cu,Zn]-SODs by visualization of bands of SOD activity in non-denaturing polyacrylamide gels and by gene probing. Strains of H. aphrophilus, $\boldsymbol{H}$. paraphrophilus, $\boldsymbol{H}$. haemolyticus, $\boldsymbol{H}$. paraphrohaemolyticus, some non-typable $\boldsymbol{H}$. influenzae, $H$. haemoglobinophilus (canis) and $H$. parasuis were all found to have $[\mathrm{Cu}, \mathrm{Zn}]-\mathrm{SOD}$ activity (inhibited by 2 mMcyanide) in polyacrylamide gels. In a Southern blot analysis, DNA from $H$. aphrophilus, $\boldsymbol{H}$. paraphrophilus, $H$. haemolyticus and $[\mathrm{Cu}, \mathrm{Zn}]-\mathrm{SOD}$-containing non-typable $\boldsymbol{H}$. influenzae - but not the other species - hybridized to a 360 nucleotide DNA probe containing the 5 'part of sodC cloned from $H$. influenzae type $b$. Bacterial $[\mathrm{Cu}, \mathrm{Zn}]-S O D s$ are more prevalent than has previously been recognized.
\end{abstract}

\section{Introduction}

Superoxide dismutases (SODs) (EC 1.15.1.1) are metalloenzymes catalysing the conversion of superoxide radicals into hydrogen peroxide and oxygen (McCord \& Fridovich, 1969). They are ubiquitous, forming an important defence against oxygen toxicity in oxygenconsuming organisms. There are two families of SODs differing in the metal(s) found at their active sites: manganese or iron, and copper/zinc. SODs containing manganese ([Mn]-SODs) occur in prokaryotes and mitochondria, while those containing iron ([Fe]-SODs) are found in prokaryotes and lower eukaryotes. Copper and zinc containing SODs ([Cu, $\mathrm{Zn}]-\mathrm{SODs})$ are principally found in eukaryotes but a few have been found in some bacteria. [Fe]- and [Mn]-SODs form one family and $[\mathrm{Cu}, \mathrm{Zn}]-\mathrm{SOD}$ another on the basis of protein sequence similarities, the two families having evolved independently under the selective pressure of oxygen toxicity (Grace, 1990).

After the first description of a bacterial [Cu, Zn]-SOD, in the fish symbiont Photobacterium leiognathi (Puget \& Michelson, 1974), numerous bacterial species have been investigated (Britton et al., 1978; Bang et al., 1978;

* Author for correspondence. Tel. (0865) 221061/221071; fax (0865) 220479.

Abbreviation: SOD, superoxide dismutase. reviewed in Hassan, 1989). Only a small number have been found to possess [Cu, $\mathrm{Zn}$ ]-SOD: Caulobacter crescentus (Steinman, 1982b), Paracoccus denitrificans (Vignais et al., 1982), Pseudomonas diminuta, Ps. maltophilia (Steinman, 1985) and Brucella abortus (Beck et al., 1990). Recently, the $[\mathrm{Cu}, \mathrm{Zn}]-\mathrm{SOD}$ gene sodC, encoding a protein very similar to the known bacterial $[\mathrm{Cu}, \mathrm{Zn}]-$ SODs (Steinman, 1982a; Steinman \& Ely, 1990; Beck $e t$ al., 1990), has been found in Haemophilus influenzae type $\mathrm{b}$ and H. parainfluenzae (Kroll et al., 1991). In this work, Haemophilus and related species have been screened for [Cu,Zn]-SOD by staining whole cell extracts separated in non-denaturing polyacrylamide gels, and by Southern hybridization to a $\operatorname{sod} C$ gene probe cloned from $H$. influenzae type $\mathrm{b}$.

\section{Methods}

Strains and culture conditions. $H$. influenzae NCTC 8468 and strains identified by RM numbers were obtained from the Departmental Culture Collection. Two further $\boldsymbol{H}$. influenzae strains were kindly provided by Dr P. Williams, University of Nottingham, UK. $\boldsymbol{H}$. aegyptius strains were kindly provided by $\mathrm{Dr}$ G. M. Carlone (Centers for Disease Control, Atlanta, USA); strain Hae7 was a Brazilian purpuric fever isolate, and strain Hae5 (NCTC 8135) a conjunctivitis control (Brenner et al., 1988). H. parasuis 857 and $H$. parasuis 870 were kindly provided by Dr J. Musser (Pennsylvania State University, USA). Taylorella equigenitalis was kindly provided by Dr A. Williams (Neurophysiology Unit, AFRC/MRC, Edinburgh, UK). Pseudomonas 
diminuta NCTC 8545 (ATCC 11568) and Ps. maltophilia NCTC 10257 (ATCC 13637) were obtained from the National Culture Type Collection, Colindale, London, UK. All other strains were obtained from the culture collection of the Public Health Laboratory Service, Oxford, UK. With the exception of the pseudomonads, strains were grown in Brain Heart Infusion broth supplemented with NAD $(2 \mu \mathrm{g}$ $\left.\mathrm{ml}^{-1}\right)$ and haemin $\left(10 \mu \mathrm{g} \mathrm{ml}^{-1}\right)$ at $37^{\circ} \mathrm{C}$ on an orbital shaker $(200$ r.p.m.) until late exponential phase, harvested and stored at $-20^{\circ} \mathrm{C}$ until required. $\boldsymbol{H}$. aphrophilus, $\boldsymbol{H}$. paraphrophilus, $\boldsymbol{H}$. parasuis and $\boldsymbol{H}$. paraphrohaemolyticus strains were additionally sparged with $5 \%(\mathrm{v} / \mathrm{v})$ carbon dioxide and sealed prior to incubation, because these strains were listed by Kilian (1976) as having enhanced growth in the presence of carbon dioxide. Ps. diminuta and Ps. maltophilia were grown to stationary phase at $30^{\circ} \mathrm{C}$ as described by Steinman (1985).

$P A G E$ conditions, $S O D$ visualization and $M_{r}$ determination. Thawed cells were suspended in $1 \mathrm{ml} 50 \mathrm{mM}$-Tris/ $\mathrm{HCl}$ (pH 7.8)-25 mM-benzamidine, sonicated for $1 \mathrm{~min}$ at $0{ }^{\circ} \mathrm{C}$, centrifuged $(13500 \mathrm{~g}, 10 \mathrm{~min})$ and the supernatants used directly or stored at $-20^{\circ} \mathrm{C}$. Measurements of protein concentration were made using the method of Bradford (1976) modified by Stoscheck (1990), using bovine serum albumin as standard.

The PAGE conditions used were $4.5 \%(\mathrm{w} / \mathrm{v}$, acrylamide $)$ stacking gel (pH 8.3) and $10 \%$ separating gel (pH 8.9) using the buffer system of Davis (1964) except that the $\mathrm{pH}$ of the upper buffer was raised to 8.9 with $10 \mathrm{M}-\mathrm{NaOH}$. SOD activity in PAGE gels was visualized by the modification of the Beauchamp \& Fridovich (1971) method as described by Steinman (1985). When used as inhibitors hydrogen peroxide or potassium cyanide were added to the riboflavin-TEMED solution to final concentrations of $5 \mathrm{mM}$ and $2 \mathrm{mM}$ respectively. [ $\mathrm{Cu}, \mathrm{Zn}$ ]-SODs are characteristically inactivated by cyanide, [Fe]-SODs by hydrogen peroxide, but [Mn]-SODs are resistant to both (Crapo et al., 1978; Dunlap \& Steinman, 1986). Bovine erythrocyte [Cu, $\mathrm{Zn}]-\mathrm{SOD}$ (Sigma) and a sonicate of Escherichia coli strain DH5 $\alpha$ containing [Fe]-, [Mn]- and hybrid [Fe,Mn]-SODs were used as appropriate controls.

The $M_{\mathrm{r}}$ values of $[\mathrm{Cu}, \mathrm{Zn}]-\mathrm{SODs}$ were estimated from the dependence of their electrophoretic mobility in PAGE gels upon acrylamide concentration (Hedrick \& Smith, 1968). Gels were prepared containing concentrations of acrylamide between $6 \%$ and $14 \%(\mathrm{w} / \mathrm{v})$, and Haemophilus extracts were compared with [Cu, $\mathrm{Zn}]-\mathrm{SOD}$ standards of known $M_{\mathrm{r}}$ as follows: Ps. maltophilia, 16000 and 20000 (Steinman, 1985); bovine erythrocyte [Cu,Zn]-SOD (Sigma), 31200 (McCord \& Fridovich, 1969); and Ps. diminuta, 45000 (Steinman, 1985). Sonicates of the Pseudomonas strains were used as the source of the $[\mathrm{Cu}, \mathrm{Zn}]-$ SODs.

Preparation and analysis of genomic DNA. DNA was prepared from 3 $\mathrm{ml}$ broth cultures as previously described (Moxon et al., 1984). Standard methods were used for restriction digestion and Southern blotting with washing to $\sim 80 \%$ stringency (Maniatis et al., 1982). Southern blots were probed with the Haemophilus DNA insert of pJSK 114. This consists of a 360 nucleotide HindIII-Ncol fragment, the 5'-part of the $H$. influenzae type b [Cu, Zn]-SOD gene sodC (Kroll et al., 1991).

\section{Results}

\section{SOD visualization in PAGE gels}

Thirty strains of bacteria predominantly from the genus Haemophilus were screened for the presence of $[\mathrm{Cu}, \mathrm{Zn}]-$ SODs. PAGE was chosen as the method for detecting enzyme activity since this has been shown to be more reliable than solution assay (Steinman, 1985). The presence or absence of SODs and their sensitivity to 2 mM-cyanide and $5 \mathrm{~mm}$-hydrogen peroxide are shown in Table 1. All strains contained a single band of SOD activity not inhibited by hydrogen peroxide or cyanide, thus characteristic of a [Mn]-SOD (Crapo et al., 1978). $T$. equigenitalis had two such bands. As this result might have been caused by the presence of catalase comigrating with the SOD, duplicate gels carrying extracts of $H$. influenzae and $H$. aegyptius were stained for this enzyme (Gregory \& Fridovich, 1974). This demonstrated that catalase was present in all these strains except NCTC 8468 and RM107, but that it migrated differently from SOD (data not shown) and was therefore not responsible for the resistance of the putative [Mn]-SOD to hydrogen peroxide. In strains of $H$. parainfluenzae, some non-typable $H$. influenzae, $H$. aphrophilus, $H$. paraphrophilus, $H$. haemolyticus, $H$. paraphrohaemolyticus, $H$. haemoglobinophilus and $\boldsymbol{H}$. parasuis, a second band of SOD activity was seen. This activity, of lower mobility than the putative [Mn]-SOD, was inhibited by cyanide but not by hydrogen peroxide, characteristics that identify it as due to [Cu,Zn]-SOD (Dunlap \& Steinman, 1986). Tracks from duplicate PAGE gels ( \pm cyanide) containing extracts from ten examples with a cyanidesensitive band are shown in Fig. 1.

The $M_{\mathrm{r}}$ values of some of these [Cu, $\mathrm{Zn}$ ]-SODs were estimated by the method of Hedrick \& Smith (1968) as follows: $H$. aphrophilus NCTC 5906, 42000; $H$. aphrophilus 1291, 39000; H. paraphrophilus NCTC 10557, $41000 ; H$. haemoglobinophilus NCTC 1659, 41500 ; $H$. paraphrophilus 1041,$33000 ; H$. parasuis 857,34000 ; and $H$. parasuis 870,16000 .

\section{Southern hybridization studies with the sodC probe pJSK114}

Southern-blotted EcoRI digests of chromosomal DNA were probed with the Haemophilus DNA insert of pJSK 114. In the case of non-influenzae strains of Haemophilus, the probe only hybridized to DNA from organisms that showed [Cu, Zn]-SOD activity in PAGE gels (Table 1). A single band of hybridization was seen with $H$. haemolyticus, $H$. aphrophilus, $H$. paraphrophilus, $H$. parainfluenzae and $H$. paraphrohaemolyticus (Fig. 2). However, $H$. haemoglobinophilus and $H$. parasuis strains, which had activity in PAGE gels, had no hybridization signals at the $80 \%$ stringency of filter-washing employed in this study (H. haemoglobinophilus, Fig. $2 ; H$. parasuis, data not shown). A newly prepared full-length gene probe for sodC from $H$. parainfluenzae 1391 in addition hybridized to chrosomal DNA from $H$. haemoglobinophilus NCTC 1659. The paradoxical observation of pJSK 114 hybridization in capsulate $H$. influenzae strains lacking $[\mathrm{Cu}, \mathrm{Zn}]-\mathrm{SOD}$ activity has been discussed at length elsewhere (Kroll et al., 1991). 
Table 1. Cyanide and hydrogen peroxide sensitivity of SODs in PAGE gels, and hybridization of chromosomal DNA to the Haemophilus influenzae type b sodC probe cloned in pJSK114

I and II correspond to phylogenetic division I or II of capsulate $H$. influenzae (Musser et al., 1988). +/indicates presence or absence of activity or probe hybridization.

\begin{tabular}{|c|c|c|c|}
\hline Strain & $\begin{array}{c}\text { SOD not } \\
\text { inhibited by } \\
5 \text { mM-peroxide } \\
\text { or } 2 \text { mM-cyanide }\end{array}$ & $\begin{array}{c}\text { SOD } \\
\text { inhibited by } \\
2 \text { mM-cyanide } \\
\text { ([Cu,Zn]-SOD) }\end{array}$ & $\begin{array}{l}\text { Hybridization } \\
\text { to insert of } \\
\text { pJSK114 }\end{array}$ \\
\hline Haemophilus influenzae RM7109 (type a, I) & + & - & $-*$ \\
\hline Haemophilus influenzae RM107 (type a, II) & + & - & $+^{*}$ \\
\hline Haemophilus influenzae RM153 (type b, I) & + & - & $-*$ \\
\hline Haemophilus influenzae NCTC 8468 (type b, II) & + & - & $t^{*}$ \\
\hline Haemophilus influenzae RM8032 (type c, I) & + & - & $-*$ \\
\hline Haemophilus influenzae RM6137 (type d, I) & + & - & $-*$ \\
\hline Haemophilus influenzae RM6157 (type e) & + & - & $+*$ \\
\hline Haemophilus influenzae RM7283 (type f, II) & + & - & $+*$ \\
\hline Haemophilus parainfluenzae 1391 & + & + & $+*$ \\
\hline Haemophilus influenzae RM8019 (non-typable) & + & - & - \\
\hline Haemophilus influenzae RM8093 (non-typable) & + & - & - \\
\hline Haemophilus influenzae 11P5 (non-typable) & + & + & + \\
\hline Haemophilus influenzae $26 \mathrm{E}$ (non-typable) & + & + & + \\
\hline Haemophilus aegyptius Haes NCTC 8135 & + & - & - \\
\hline Haemophilus aegyptius Hae7 & + & - & - \\
\hline Haemophilus aphrophilus NCTC 5906 & + & + & + \\
\hline Haemophilus aphrophilus 1291 & + & + & + \\
\hline Haemophilus paraphrophilus NCTC 10557 & + & + & + \\
\hline Haemophilus paraphrophilus 1041 & + & + & + \\
\hline Haemophilus haemolyticus NCTC 10659 & + & + & + \\
\hline Haemophilus paraphrohaemolyticus NCTC 10670 & + & + & + \\
\hline Haemophilus haemoglobinophilus NCTC 1659 & + & + & - \\
\hline Haemophilus parasuis NCTC 4557 & + & + & - \\
\hline Haemophilus parasuis 857 & + & + & - \\
\hline Haemophilus parasuis 870 & + & + & - \\
\hline Haemophilus avium NCTC 11297 & + & - & - \\
\hline Haemophilus paragallinarum NCTC 11296 & + & - & - \\
\hline Haemophilus segnis NCTC 10977 & + & - & - \\
\hline Eikenella corrodens NCTC 10596 & + & - & - \\
\hline Taylorella equigenitalis & $+t$ & - & - \\
\hline
\end{tabular}

* Data from Kroll et al. (1991).

$\uparrow$ Two SOD bands.

\section{Discussion}

All the Haemophilus and related species examined in this study possess a SOD with activity resistant to cyanide and hydrogen peroxide, typical of the [Mn]-containing enzyme. A wide range of $R_{F}$ values $(0.25-0.83$ in $10 \%$ PAGE gels) was obtained for these enzymes (data not shown) suggesting structural heterogeneity as reported before for [Mn]-SODs (Steinman, 1983). In addition, strains of $H$. parainfluenzae, some non-typable $H$. influenzae, $H$. aphrophilus, $H$. paraphrophilus, $H$. haemolyticus, $\boldsymbol{H}$. paraphrohaemolyticus, $\boldsymbol{H}$. haemoglobinophilus and $H$. parasuis were found to possess a second enzyme with activity characteristic of [Cu,Zn]-SOD. This study has thus considerably extended the known number of $[\mathrm{Cu}, \mathrm{Zn}]-\mathrm{SODs}$ in bacteria. In fact it has been argued before that the reported rarity of bacterial $[\mathrm{Cu}, \mathrm{Zn}]-\mathrm{SODs}$ may be more apparent than real, as although a considerable range of micro-organisms has been examined, in many cases only one strain has been investigated, and in any case, the molecular heterogeneity of these enzymes and in particular their high isoelectric point makes their detection difficult without particular attention to gel conditions (Steinman, 1985). The $M_{\mathrm{r}}$ determinations presented here suggest a degree of molecular heterogeneity within $[\mathrm{Cu}, \mathrm{Zn}]-\mathrm{SODs}$ of Haemophilus species. With the exception of $[\mathrm{Cu}, \mathrm{Zn}]-\mathrm{SOD}$ from $H$. parasuis 870, all the other Haemophilus $[\mathrm{Cu}, \mathrm{Zn}]-$ SODs had estimated $M_{\mathrm{r}}$ values greater than the 31500 and 29200 reported for the enzymes from $P$. leiognathi (Steinman, 1982a) and C. crescentus (Steinman \& Ely, 1990) respectively, although none were as high as the 45000 of Ps. diminuta (Steinman, 1985). The apparent high $M_{r}$ of $[\mathrm{Cu}, \mathrm{Zn}]-S O D$ in this last species was 


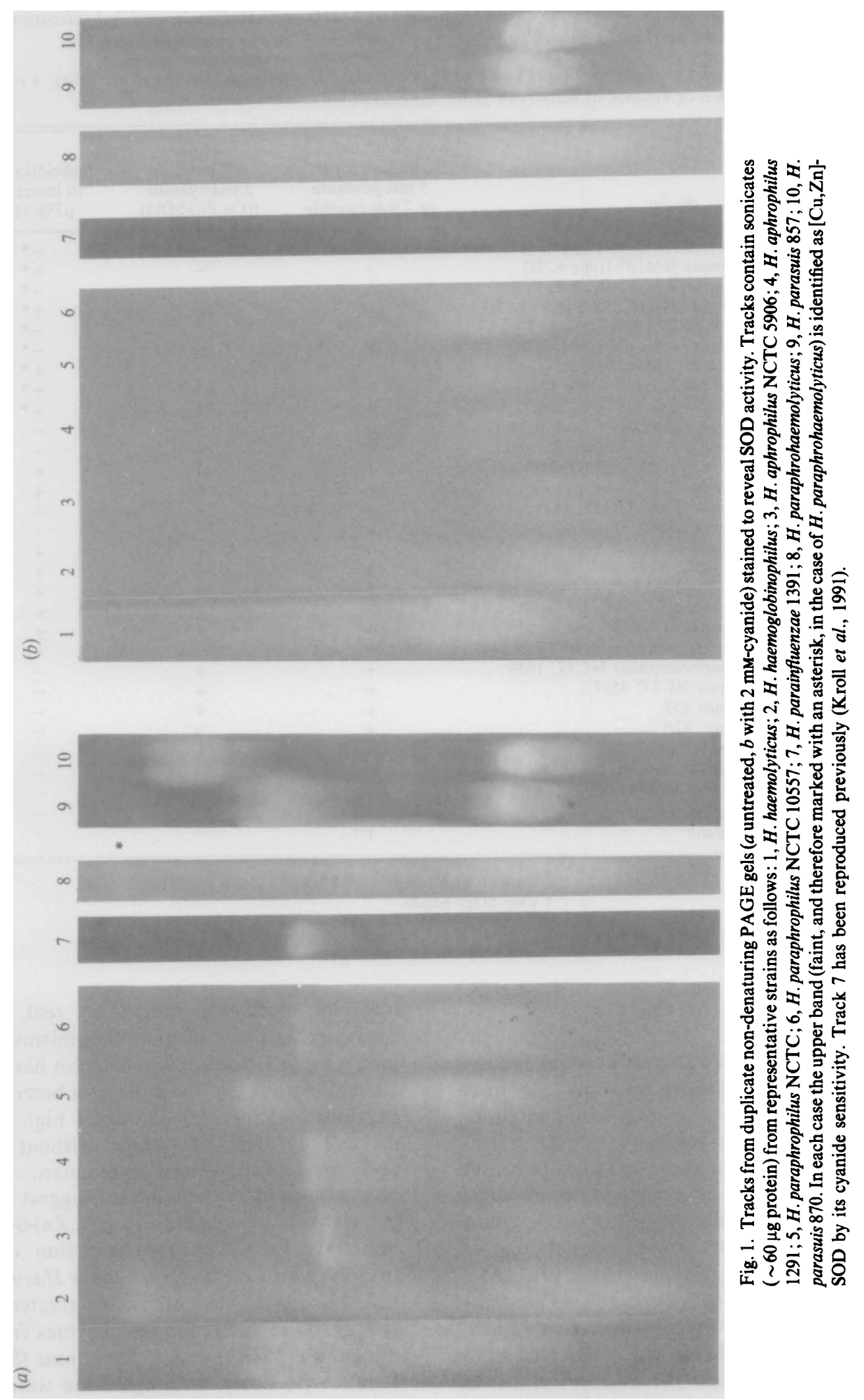




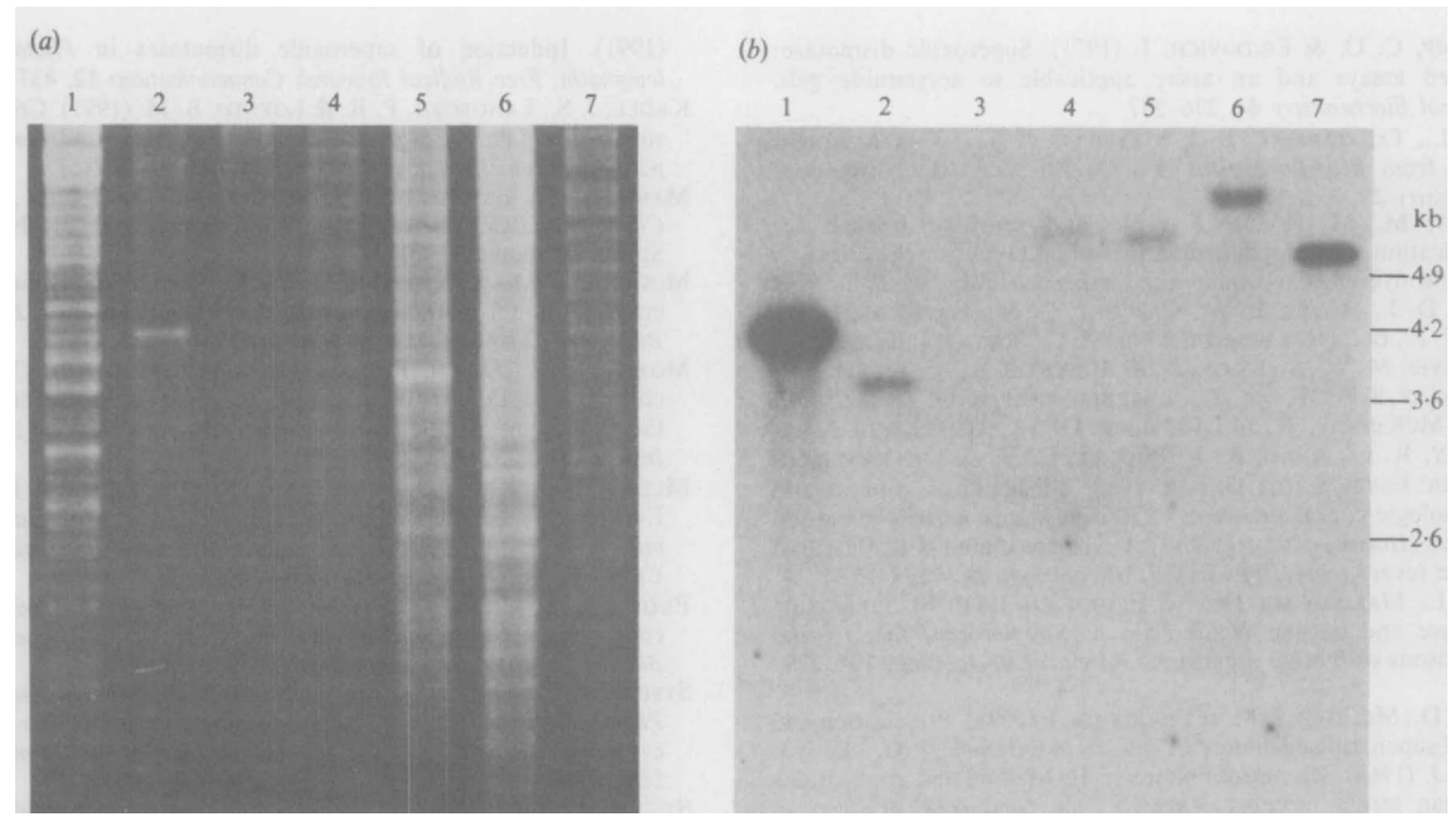

Fig. 2. Southern hybridization of sodC DNA to different Haemophilus species. (a) Electrophoretically separated EcoRI-digested DNA visualized in an agarose gel by staining with ethidium bromide. (b): Southern blot of the same gel. Tracks contain DNA from strains as follows: $1, H$. influenzae type b NCTC $8468 ; 2, H$. haemolyticus; $3, H$. haemoglobinophilus; $4, H$. aphrophilus NCTC $5906 ; 5, H$. paraphrophilus $1041 ; 6, H$. paraphrophilus NCTC $10557 ; 7, H$. parainfluenzae 1391 . DNA fragment size markers (kb) are indicated on the right. The estimated size of the single hybridization band of $H$. paraphrophilus NCTC 10557 is $6.8 \mathrm{~kb}$.

attributed to asymmetry of the protein altering its mobility in PAGE gels, and the same explanation may apply here. Native [Cu,Zn]-SODs are generally dimers composed of identical subunits (Steinman, 1983). The low $M_{\mathrm{r}}(16000)$ estimated for the $H$. parasuis 870 enzyme may be that of the monomeric subunit, found here due to instability of the enzyme at $\mathrm{pH} 8.9$ and reassociation at pH 7.8 upon SOD visualization, as has been suggested for the Ps. maltophilia enzyme (Steinman, 1985).

DNA hybridization using the $H$. influenzae type b sodC probe pJSK114 suggests that in each of these Haemophilus species, [Cu, $\mathrm{Zn}]-\mathrm{SOD}$ activity is encoded by an homologous gene. Where the probe failed to hybridize to chromosomal DNA despite the presence of [Cu, $\mathrm{Zn}]-\mathrm{SOD}$ activity, it may be that sequence divergence greater than the limit of $20 \%$ reliably detectable in these experiments was responsible. Such divergence has been found in a gene homologous to sodC that has now been cloned from Actinobacillus pleuropneumoniae (unpublished results).

Visualization of enzyme activity in PAGE gels has been considered the method of choice for screening for $[\mathrm{Cu}, \mathrm{Zn}]-\mathrm{SODs}$, as it is simple and more accurate than solution assay (Steinman, 1985). The use of [Cu, Zn]-SOD gene probes like pJSK 114 can greatly extend the scope of investigations, particularly where SOD activity is too low to be detected as in strains with modified or inactivated enzyme. Kroll et al. (1991) found that a CAT $\rightarrow$ TAT transition in the structural gene, mutating a critical histidine to tyrosine, was most likely responsible for the lack of [ $\mathrm{Cu}, \mathrm{Zn}]-\mathrm{SOD}$ activity in $H$. influenzae type b. $[\mathrm{Cu}, \mathrm{Zn}]-\mathrm{SOD}$ activity may not be detected where experiments are carried out under non-permissive conditions where expression of the enzyme is environmentally regulated. Such environmental regulation of bacterial [Cu, $\mathrm{Zn}]-\mathrm{SOD}$ expression has been shown in the case of $P$. leiognathi (Kobayashi et al., 1991).

DNA probes like pJSK 114 will be important tools to facilitate the cloning of homologous [Cu, $\mathrm{Zn}]-\mathrm{SOD}$ genes from other species in order to study the role of this enzyme in the biology of oro-pharyngeal commensals and pathogens.

This work was supported by grants to J.S.K. from the Wellcome Trust and the British Lung Foundation.

\section{References}

Bang, S. S., Woolkalis, M. J. \& BaumanN, P. (1978). Electrophoretic mobilities of superoxide dismutases from species of Photobacterium, Beneckea, Vibrio, and selected terrestrial enterobacteria. Current Microbiology 1, 371-376. 
Beauchamp, C. O. \& Fridovich, I. (1971). Superoxide dismutase: improved assays and an assay applicable to acrylamide gels. Analytical Biochemistry 44, 276-287.

Beck, B. L., Tabatabai, L. B. \& MaYfield, J. E. (1990). A protein isolated from Brucella abortus is a $\mathrm{Cu}-\mathrm{Zn}$ superoxide dismutase. Biochemistry 29, 372-376.

BRADFORD, M. M. (1976). A rapid and sensitive method for quantification of microgram quantities of protein using the principle of protein dye binding. Analytical Biochemistry 72, 248-254.

Brenner, D. J., Mayer, L. W., Carlone, G. M., Harrison, L. H., Bibb, W. F., DeCunto Brandileone, M. C., SotTneK, F. O., Irino, K., Reeves, M. W., Swenson, J. M., Birkness, K. A., Weyant, R. S., Berkley, S. F., WoOds, T. C., Steiger Walt, A. G., Grimont, P. A. D., McKinney, R. M., Fleming, D. W., Gheesling, L. L., Cooksey, R. C., Arko, R. J., Broome, C. V. \& The Brazillan PURPURIC FeVER StUdY Group (1988). Biochemical, genetic, and epidemiologic characterization of Haemophilus influenzae biogroup aegyptius (Haemophilus aegyptius) strains associated with Brazilian purpuric fever. Journal of Clinical Microbiology 26, 1524-1534.

Britton, L., Malinowski, D. P. \& Fridovich, I. (1978). Superoxide dismutase and oxygen metabolism in Streptococcus faecalis and comparisons with other organisms. Journal of Bacteriology 134, 229236.

Crapo, J. D., MCCoRD, J. M. \& Fridovich, I. (1978). Preparation and assay of superoxide dismutases. Methods in Enzymology 53, 382-393.

DAVIS, B. J. (1964). Disc electrophoresis. II. Method and applications to human serum proteins. Annals of the New York Academy of Sciences 121, 404-427.

DunLaP, P. V. \& Steinman, H. W. (1986). Strain variation in bacteriocuprein superoxide dismutase from symbiotic Photobacterium leiognathi. Journal of Bacteriology 165, 393-398.

GraCE, S. C. (1990). Phylogenetic distribution of superoxide dismutase supports an endosymbiotic origin for chloroplasts and mitochondria. Life Sciences 47, 1875-1886.

GREGORY, E. M. \& FRIDOVICH, I. (1974). Visualization of catalase on acrylamide gels. Analytical Biochemistry 58, 57-62.

Hassan, M. H. (1989). Microbial superoxide dismutases. Advances in Genetics 26, 65-97.

HeDRICK, J. L. \& SMITH, A. J. (1968). Size and charge isomer separation and estimation of molecular weights of proteins by disc gel electrophoresis. Archives of Biochemistry 126, 155-164.

KILIAN, M. (1976). A taxonomic study of the genus Haemophilus, with the proposal of a new species. Journal of General Microbiology 93, 9-62.

Kobayashn, H., Tonokawa, H., Fukasawa, S. \& Yamakura, F.
(1991). Induction of superoxide dismutases in Photobacterium leiognathi. Free Radical Research Communications 12, 437-441.

Kroll, J. S., LANGFord, P. R. \& LoYNDS, B. M. (1991). Copper/zinc superoxide dismutases in Haemophilus influenzae and Haemophilus parainfluenzae. Journal of Bacteriology 173, 7449-7457.

MANIATIS, T., Fritsch, E. F. \& SAMBrOOK, J. (1982). Molecular Cloning: a Laboratory Manual. Cold Spring Harbor, NY: Cold Spring Harbor Laboratory.

MCCoRD, J. M. \& Fridovich, I. (1969). Superoxide dismutase. An enzymic function for erythrocuprein (hemocuprein). Journal of Biological Chemistry 244, 6049-6055.

Moxon, E. R., DEICH, R. A. \& CONNELly, C. (1984). Cloning of chromosomal DNA from Haemophilus influenzae. Its use for studying the expression of type b capsule and virulence. Journal of Clinical Investigation 73, 298-306.

Musser, J. M., Kroll, J. S., Moxon, E. R. \& Selander, R. K. (1988). Evolutionary genetics of the encapsulated strains of Haemophilus influenzae. Proceedings of the National Academy of Sciences of the United States of America 85, 7758-7762.

Puget, K. \& Michelson, A. M. (1974). Isolation of a new copper containing superoxide dismutase. Bacteriocuprein. Biochemical and Biophysical Research Communications 58, 830-838.

Steinman, H. M. (1982a). Bacteriocuprein superoxide dismutase of Photobacterium leiognathi. Isolation and sequence of the gene and evidence for a precursor form. Journal of Biological Chemistry 262, 1882-1887.

Steinman, H. M. (1982b). Copper-zinc superoxide dismutase from Caulobacter crescentus CB15. A novel bacteriocuprein form of the enzyme. Journal of Biological Chemistry 257, 10283-10293.

Steinman, H. M. (1983). Superoxide dismutases: protein chemistry and structure-function relationships. In Superoxide Dismutase, vol. 1, pp. 11-68. Edited by L. W. Oberley. Boca Raton, Fla: CRC Press.

Steinman, H. M. (1985). Bacteriocuprein superoxide dismutases in pseudomonads. Journal of Bacteriology 162, 1255-1260.

Steinman, H. M. \& ElY, B. (1990). Copper-zinc superoxide dismutase of Caulobacter crescentus: cloning, sequencing, and mapping of the gene and periplasmic location of the enzyme. Journal of Bacteriology 172, 901-2910.

Stoscheck, C. M. (1990). Increased uniformity in the response of Coomassie Blue $\mathrm{G}$ protein assay to different proteins. Analytical Biochemistry 184, 111-116.

Vignais, P. M., Terech, A., Meyer, C. M. \& HenRy, M.-F. (1982), Isolation and characterization of a protein with cyanide-sensitive superoxide dismutase activity from the prokaryote Paracoccus denitrificans. Biochimica et Biophysica Acta 701, 305-317. 